\title{
Solid Phase Extraction of Rare Earth Elements in Deep Groundwater With Multi-wall Carbon Nanotubes as Adsorbent for the Determination by Inductively Coupled Plasma Mass Spectrometry
}

\author{
Jaiangyi Zhang ${ }^{\mathrm{a}}$, Xiaoju Wang ${ }^{\mathrm{b}}$, Yanhui Dong ${ }^{\mathrm{a}, \mathrm{c}^{*}}$, Zhifang $\mathrm{Xu}^{\mathrm{a}}$, and Guomin $\mathrm{Li}^{\mathrm{a}}$ \\ ${ }^{a}$ Key Laboratory of Shale Gas and Geoengineering, Institute of Geology and Geophysics, \\ Chinese Academy of Sciences, Beijing 100029, P.R. China \\ ${ }^{b}$ Beijing Municipal Environmental Monitoring Center, Beijing 100048, P.R. China \\ ' State Key Laboratory of Coal Resources and Safe Mining, China University of Mining \& Technology, \\ P.O. BOX 9825, Beijing 100029, P.R. China
}

\section{INTRODUCTION}

Rare earth elements (REEs) have unique chemical properties and are important hydrogeochemical and diagnostic tools for natural and anthropogenic processes (1-5) such as tracing water mass formation (6) and as oxidation reduction potential probes (7) in groundwater. The accurate determination of REEs in groundwater is necessary for hydrogeochemical and environmental chemistry.

Inductively coupled plasma mass spectrometry (ICP-MS) is well known for its excellent sensitivity, precision, and accuracy, and is a compatible technique commonly used for the simultaneous determination of REEs. However, the concentrations of REEs in groundwater, especially in deep groundwater samples, are usually at sub-parts per trillion (sub-ng L ${ }^{-1}$ ) levels, and are difficult to determine directly by ICP-MS. Therefore, an efficient separation and pre-concentration step prior to REE determination is required (8). Several co-precipitation (9-10), solvent extraction (1113), solid phase extraction (SPE) (14-16), and ion exchange (17-18) techniques have been developed for the enrichment of REEs. Among these methods, SPE is one of the important pre-concentration methods used in environmental analysis

*Corresponding autbor.

E-mail: lemondyb@mail.iggcas.ac.cn

Tel: (+86) 10-82998557

Fax: (+86) 10-62010846

\section{ABSTRACT}

A solid phase preconcentration method has been developed using hydroxyl multi-wall carbon nanotubes (MWNTs) as the absorbent. The method was optimized for the determination of rare earth elements (REEs) in deep groundwater samples by inductively coupled plasma mass spectrometry (ICP-MS). The effects of the experimental parameters, including $\mathrm{pH}$, eluent concentration and volume, flow rates of sample and eluent solutions, and the sample volume on the recoveries of the analytes were examined in detail. Under optimum conditions, REEs can be quantitatively retained by MWNTs when the $\mathrm{pH}$ exceeds 3.0 and are then eluted completely with $1 \% \mathrm{HNO}_{3}$. The detection limits of this method ranged from $0.31 \mathrm{ng} \mathrm{L}^{-1}$ to $1.2 \mathrm{ng}$ $\mathrm{L}^{-1}$ and the relative standard deviations (RSDs) were less than 5\%. The method was validated using a certified reference material and was applied for the determination of REEs in deep groundwater samples with satisfactory results.

due to its simple operation, high enrichment factor, ability to deal with large volumes of sample solution, and low cost.

The choice of sorbent is important in the efficacy of solid phase extraction procedures. In general, an ideal adsorbent material should possess high capacity, long lifetime, and the ability to extract a suite of elements quantitatively within a wide $\mathrm{pH}$ range (19-20). Nano-materials have good potential in terms of sample separation and enrichment because of their high specific surface area and excellent absorption properties, but currently the research in sample pretreatment with nano-materials is limited. Carbon nanotubes (CNTs) have attracted great attention because of their unique properties and their use as solid phase extraction adsorbents began in 2003 (21). Carbon nanotubes, which have surface hydroxyl, carboxyl, and other hydrophilic groups, can produce strong adsorption of heavy metal ions by electrostatic or chelation, and can be used to extract metal ions such as $\mathrm{Cd}^{2+}, \mathrm{Cu}^{2+}, \mathrm{Ni}^{2+}, \mathrm{Pb}^{2+}$, $\mathrm{Zn}^{2+}, \mathrm{Cr}^{6+}, \mathrm{Co}^{2+}$, and $\mathrm{Au}^{2+}$ in water, soil, food, or biological samples (22-26). In addition, carbon nanotubes also have an efficient extraction enrichment capability for REEs (27) and organometallic compounds (28).

In this study, the potential of multi-wall carbon nanotubes (MWNTs) as an adsorbent in extracting REEs in deep groundwater samples was investigated. The potential factors affecting SPE separation of the analytes were optimized and are discussed in detail. On the basis of the experimental results obtained, a novel method using SPE coupled with inductively coupled plasma mass spectrometry (ICP-MS) was devel- 
oped for the simultaneous determination of trace REEs in deep groundwater samples.

\section{EXPERIMENTAL}

\section{Instrumentation}

A PerkinElmer ${ }^{\circledR}$ ELAN ${ }^{\circledR}$ DRC $^{\text {TM }}$-e (Dynamic Reaction Cell ${ }^{\mathrm{TM}}$ ) ICP-MS instrument was used (PerkinElmer, Inc., Shelton, CT, USA). The sample introduction system is comprised of a PC3 Peltier cyclonic spray chamber (Elemental Scientific Inc., USA) with a $1.0-\mathrm{mm}$ i.d. quartz injector. The typical operating parameters of the DRCICP-MS used for this work are summarized in Table I. The $\mathrm{pH}$ values were measured with a Mettler Toledo 320-S pH meter (Mettler Toledo Instruments, Shanghai, P.R. China) supplied with a combined electrode. The SPE experiments were performed on a 12-tube solidphase device with a vacuum pump (Dikma Technologies Inc., Beijing, P.R. China)

\section{Reagents and Standard Solutions}

High-purity water (18.2 M $\Omega$ $\mathrm{cm}^{-1}$ ) was used throughout this work and obtained with a Milli-Q ${ }^{\circledR}$ Direct 8 water purification system (Millipore Corporation, France). Nitric acid $\left(\mathrm{HNO}_{3}, 65-70 \%, \mathrm{w} / \mathrm{w}\right.$, 99.9999\%) and ammonium hydroxide $\left(\mathrm{NH}_{4} \mathrm{OH}, 28-30 \%\right.$, w/w, 99.9999\%) were purchased from Beijing Chemical Reagent Research Institute. REE stock standard solutions in the amount of $10 \mathrm{mg} \mathrm{L}^{-1}$ were obtained from PerkinElmer, Inc., Shelton, CT, USA. The working standard solutions were prepared by diluting the stock standard solutions. The empty SPE cartridges $(6 \mathrm{~mL})$ and SPE frits were purchased from Dikma Technologies Inc., Beijing, P.R. China. Hydroxyl multi-wall carbon nanotubes (MWNTs) (diameter 10-20 nm, length 10-30 $\mu \mathrm{m}$, purity >95wt\%, - OH content 3.06wt \%) were purchased from Chengdu Organic Chemical Co., Ltd. (Chengdu, P.R. China).

\section{Reference Materials}

The reference material SPS-SW1 Surface Water (LGC Standards, USA) containing $0.5 \mathrm{ng} \mathrm{mL}^{-1}$ REEs was used to validate the quality of the SPE-ICP-MS measurements. For applicability of the low REE concentrations expected in deep groundwater, the SPS-SW1 standard was diluted 1:10.

\section{Preparation of Solid Phase Extraction Column}

A 20-mg amount of MWNTs was introduced into a blank reservoir of 6-mL capacity, plugged with SPE frits at both ends. Before each use, $5 \mathrm{~mL} \mathrm{1 \%} \mathrm{HNO}_{3}(\mathrm{v} / \mathrm{v})$ solution and $10 \mathrm{~mL}$ high-purity water were passed through the column in order to clean and condition it. Then the column was conditioned to the desired $\mathrm{pH}$ with $10 \mathrm{~mL} \mathrm{HNO}_{3}$ and $\mathrm{NH}_{3} \cdot \mathrm{H}_{2} \mathrm{O}$ solution. The flow rate of the passing solutions was set at $2 \mathrm{~mL} \mathrm{~min}^{-1}$.

\section{SPE Procedure}

A portion of the aqueous sample solution containing REEs was prepared and the solutions $(50 \mathrm{~mL})$ adjusted to the desired $\mathrm{pH}$ values between 6 and 8 with diluted $\mathrm{HNO}_{3}$ and $\mathrm{NH}_{3} \cdot \mathrm{H}_{2} \mathrm{O}$, then passed through the column at a flow rate

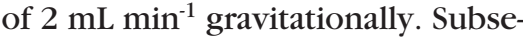
quently, the REEs retained on the MWNTs were eluted with $2 \mathrm{~mL} \mathrm{1 \%}$ $\mathrm{HNO}_{3}$. The eluent was collected in a 2-mL polyethylene pipe and directly analyzed by ICP-MS. The column could be used repeatedly after regeneration with $5 \mathrm{~mL} \mathrm{1 \%}$ $\mathrm{HNO}_{3}$ (v/v) solution and $10 \mathrm{~mL}$ high-purity water.

\section{Deep Groundwater Samples}

The groundwater samples were obtained from 500-meter deep wells (Gansu province, P.R. China), placed into polyethylene bottles, and filtered through a $0.45-\mu \mathrm{m}$ membrane. Until analysis, the water samples were stored at $4{ }^{\circ} \mathrm{C}$.

TABLE I

ICP-MS Instrumental Operating Parameters

$\begin{array}{ll}\text { Instrumentation } & \text { PerkinElmer }{ }^{\circledR} \text { ELAN }{ }^{\circledR} \text { DRC }{ }^{\mathrm{TM}}-\mathrm{e} \text { ICP-MS } \\ \text { Sample introduction } & \text { PFA-400 Micro Flow nebulizer } \\ \text { Spray chamber } & \begin{array}{l}\text { Cyclonic spray chamber (PC3 Peltier Chiller), } \\ \text { room temperature }\end{array} \\ \text { Injector tube } & 1.0 \mathrm{~mm} \text { i.d. quartz } \\ \text { RF power } & 1350 \mathrm{~W} \\ \text { Plasma gas flow } & 16 \mathrm{~L} \mathrm{~min}{ }^{-1} \\ \text { Auxiliary gas flow } & 1.0 \mathrm{~L} \mathrm{~min}{ }^{-1} \\ \text { Nebulizer gas flow } & 0.81 \mathrm{~L} \mathrm{~min}^{-1} \\ \text { Auto Lens } & \mathrm{On} \\ \text { Dwell time } & 50 \mathrm{~ms} \\ \text { Sweeps } & 32 \\ \text { Readings } & 1 \\ \text { Replicate } & 3 \\ \text { Cones } & \mathrm{Ni} \\ \text { Selected isotope } & { }^{139} \mathrm{La},{ }^{140} \mathrm{Ce},{ }^{141} \mathrm{Pr},{ }^{142} \mathrm{Nd},{ }^{152} \mathrm{Sm},{ }^{153} \mathrm{Eu},{ }^{158} \mathrm{Gd}, \\ & { }^{159} \mathrm{~Tb},{ }^{164} \mathrm{Dy},{ }^{165} \mathrm{Ho},{ }^{166} \mathrm{Er},{ }^{169} \mathrm{Tm},{ }^{174} \mathrm{Yb},{ }^{175} \mathrm{Lu}\end{array}$




\section{RESULTS AND DISCUSSION}

\section{Effect of pH on Adsorption}

The $\mathrm{pH}$ value plays an important role for the quantitative adsorption of metal ions during the SPE procedure. The effect of the solution $\mathrm{pH}$ (ranging from 1-10) on the retention of REEs on the MWNTs is illustrated in Figure 1. It can be seen that quantitative adsorption (>95\%) for the REEs was obtained when the $\mathrm{pH}$ exceeded 3.0. For general groundwater samples, the REEs can be directly adsorbed onto MWNTs and no additional $\mathrm{pH}$ adjustment is needed. For the following experiments, the $\mathrm{pH}$ of the solution used was 6.5 as the compromise condition.

\section{Effect of Eluent Concentration and Volume}

The eluent is an important parameter in the SPE process which can influence the enrichment performance. Various concentrations of $\mathrm{HNO}_{3}$ were used for elution of the REEs from the MWNTs. The results obtained are given in Figure 2. It was found that $1 \% \mathrm{HNO}_{3}$ was sufficient for quantitative elution (>95\%). In addition, the effect of eluent volume on the recovery of the REEs was also studied by keeping the $\mathrm{HNO}_{3}$ concentration at $1 \%$. It was found that quantitative recoveries ( $>95 \%$ ) could be obtained with $2 \mathrm{~mL} \mathrm{HNO}_{3}$ (Table II). Therefore, $2.0 \mathrm{~mL}$ of $1 \% \mathrm{HNO}_{3}$ was used as the eluent in the following experiments.

\section{Flow Rate of Sample and Eluent Solutions}

The flow rate of the sample affects the retention of REEs on the adsorbent, while the flow rate of the eluent affects the recoveries of the REEs. Therefore, the effect of

\section{Atomic Apectroscopy \\ 1 Vol. 37(1), Jan./Feb. 2016}

the flow rates of the sample and eluent solutions were examined under the optimum conditions $(\mathrm{pH}$, eluent concentration, and volume). It was found that the flow rate of the sample and the eluent solutions had no significant influence on the recoveries of the REEs in the range of $0.5-5.0 \mathrm{~mL}$ and $0.5-2.0 \mathrm{~mL}$, respectively.

\section{Effect of Sample Volume}

In order to obtain a high concentration factor, the effect of sample volume on the sorption behavior of REEs on the MWNTs was explored by passing $50-500 \mathrm{~mL}$ of solutions containing $50 \mathrm{ng}$ REEs through the SPE column. It was found that sorption of the REE ions was not affected at a sample volume between 50 and $500 \mathrm{~mL}$ and the quantitative recoveries were $>95 \%$. In this study, the REEs were quantitatively recovered using a $2.0-\mathrm{mL}$

TABLE II

Effect of $\mathrm{HNO}_{3}$ Volume on REE Recoveries (\%) From the MWNT Column (REEs: $1 \mu \mathrm{g} \mathrm{L}^{-1}$, sample volume: $50 \mathrm{~mL}$ )

\begin{tabular}{lllllllllllllll}
\hline & $\mathrm{Ce}$ & $\mathrm{Pr}$ & $\mathrm{Nd}$ & $\mathrm{Sm}$ & $\mathrm{Eu}$ & $\mathrm{Gd}$ & $\mathrm{Tb}$ & $\mathrm{Dy}$ & $\mathrm{Ho}$ & $\mathrm{Er}$ & $\mathrm{Tm}$ & $\mathrm{Yb}$ & $\mathrm{Lu}$ & $\mathrm{La}$ \\
\hline $0.5 \mathrm{~mL}$ & 50.7 & 58.6 & 58.2 & 57.4 & 58.7 & 57.8 & 57.7 & 58.9 & 59.1 & 59.7 & 58.4 & 56.8 & 57.1 & 64.6 \\
$1.0 \mathrm{~mL}$ & 77.8 & 80.8 & 87.0 & 78.8 & 80.0 & 79.8 & 81.0 & 78.8 & 81.6 & 81.0 & 81.2 & 79.0 & 80.4 & 85.2 \\
$2.0 \mathrm{~mL}$ & 98.6 & 97.4 & 101.4 & 95.6 & 95.2 & 96.5 & 99.1 & 95.8 & 98.6 & 99.1 & 101.4 & 99.7 & 100.8 & 98.6 \\
\hline
\end{tabular}

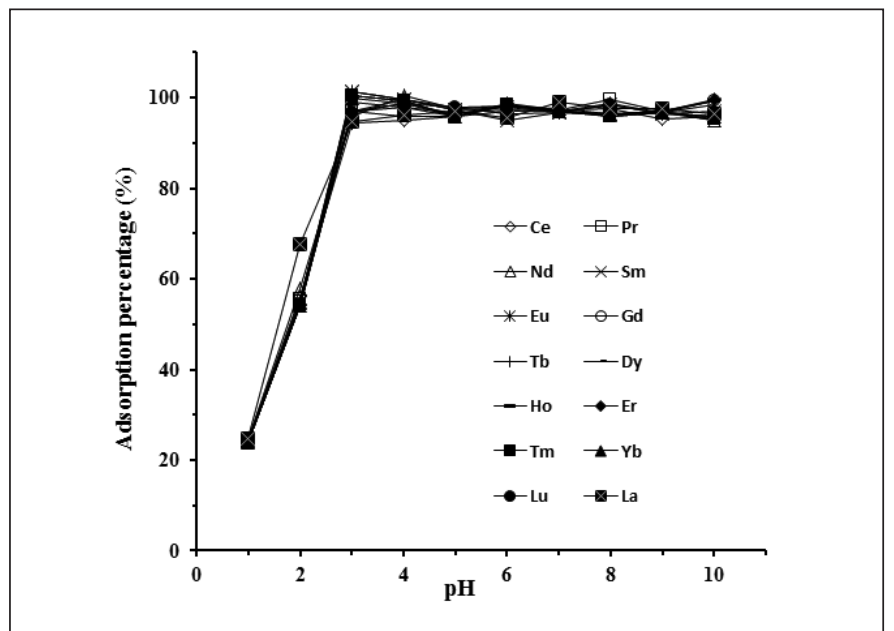

Fig. 1. Effect of $p H$ on the adsorption of the REEs on MWNTs, REEs: $1 \mu \mathrm{g} \mathrm{L} \mathrm{L}^{-1}$, sample volume: $50 \mathrm{~mL}$, eluent: $1 \% \mathrm{HNO}_{3}$.

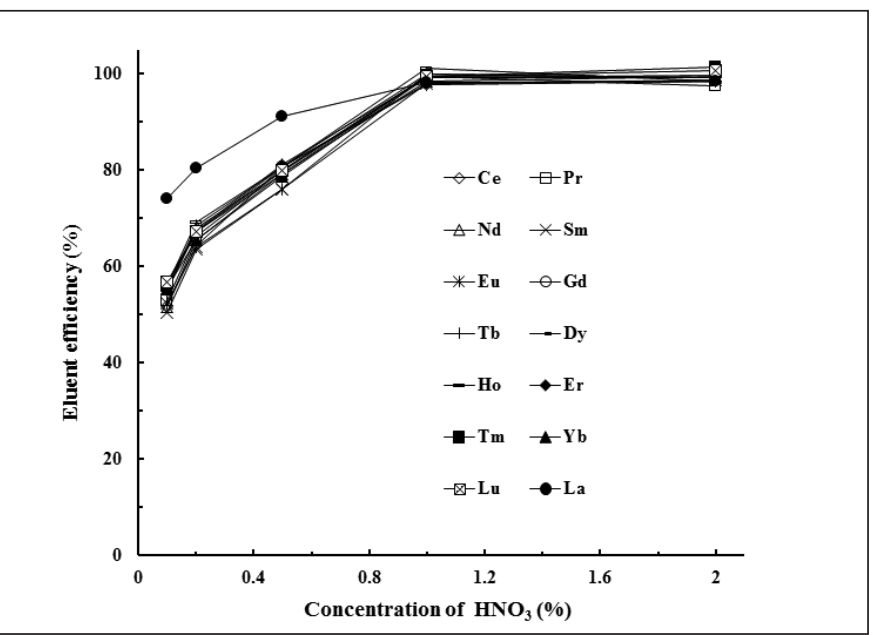

Fig. 2. Effect of $\mathrm{HNO}_{3}$ concentration on eluent efficiency (\%) of REEs from MWNT column. REEs: $1 \mu \mathrm{g} \mathrm{L}^{-1}$, sample volume: $50 \mathrm{~mL}$. 
volume of $1 \% \mathrm{HNO}_{3}$, and an enrichment factor of 25 was achieved using 50-mL sample solutions.

\section{Adsorption Capacity}

The adsorption capacity of the MWNTs towards REEs was estimated at a $\mathrm{pH}$ of 6.5 by passing $50 \mathrm{~mL}$ of $10 \mathrm{mg} \mathrm{L}^{-1}$ of each REE into $20 \mathrm{mg}$ MWNTs packed in the cartridge and preconditioned as described earlier in "Preparation of Solid Phase Extraction Column." The adsorbed REEs were eluted with $2 \mathrm{~mL}$ of $1 \% \mathrm{HNO}_{3}$. The amount of REE ions adsorbed was determined by ICP-MS. The adsorption capacity of the MWNTs for each REE is summarized in Table III. It can be seen that the MWNTs have a large capacity for the simultaneous preconcentration of REEs in natural water samples.

\section{Column Re-use}

The stability of the column was monitored during the course of the method optimization studies. The column can be re-used after regeneration with $10 \mathrm{~mL} 1 \% \mathrm{HNO}_{3}$ and $20 \mathrm{~mL}$ high-purity water, and is stable for up to 50 adsorption-elution cycles without an obvious decrease in the recoveries of the REEs.

\section{Matrix Effects}

In order to assess the possible analytical applications of the recommended procedure, the interference of several cations and anions was examined under the optimized conditions. The experimental results are summarized in Table IV. The tolerance limit is defined as the largest amount of coexisting ions causing $\pm 5 \%$ error in the determination of the analytes. It was observed that the ions normally present in natural water had no obvious influence on the adsorption of REEs under the selected conditions.

\section{Analytical Performance}

With regard to the determination of REEs by ICP-MS, it should be pointed out that the oxide ions of light REEs interfere on the measurement of heavy REEs. The main interference comes from the formation of the oxide $\left(\mathrm{MO}^{+}\right)$and hydroxide $\left(\mathrm{MOH}^{+}\right)$during the sampling process, and corrections should be done. Table $\mathrm{V}$ shows the main interference observed in REE analysis. Corrections for the oxide and hydroxide overlap on ${ }^{153} \mathrm{Eu}^{+}$, ${ }^{158} \mathrm{Gd}^{+},{ }^{59} \mathrm{~Tb}^{+},{ }^{164} \mathrm{Dy}^{+},{ }^{166} \mathrm{Er}^{+},{ }^{174} \mathrm{Yb}^{+}$ and ${ }^{175} \mathrm{Lu}^{+}$were made by determining $100 \mathrm{mg} \mathrm{L}^{-1}$ pure $\mathrm{Ce}, \mathrm{Pr}, \mathrm{Nd}, \mathrm{Sm}$, $\mathrm{Gd}$, and Tb solution, respectively, and calculating the percentage contribution of $\mathrm{MO}^{+}$and $\mathrm{MOH}^{+}$to the analyzed isotopes. With the instrument used and the conditions given in Table I, the yield of $\mathrm{MOH}^{+}$was nearly one order of magnitude lower than that of the corresponding $\mathrm{MO}^{+}$, and generally the $\mathrm{MO}^{+} / \mathrm{M}^{+}$ ratio was less than $1.5 \%$ and the $\mathrm{MOH}^{+} / \mathrm{M}^{+}$ratio less than $0.2 \%$. Based on these data, the interference correction for light REE oxide ions was not carried out. Because the concentrations of $\mathrm{Ba}$ in deep groundwater are low (at dozens of $\mathrm{Pb}$ ) and in the experimental conditions the adsorption efficiency of $\mathrm{Ba}$ on the column was very low, the interference caused by Ba could be ignored.

Under the optimized conditions, the calibration graphs were linear up to $1 \mathrm{ng} \mathrm{mL} \mathrm{m}^{-1}$ for the studied REEs with a correlation coefficient in the range of $0.9985-0.9997$. The detection limits were $0.31-1.2 \mathrm{ng} \mathrm{L}^{-1}$

\section{TABLE III}

Adsorption Capacity of MWNTs for REEs

\begin{tabular}{|c|c|c|c|c|c|c|c|c|c|c|c|c|c|c|}
\hline & $\mathrm{Ce}$ & $\operatorname{Pr}$ & $\mathrm{Nd}$ & $\mathrm{Sm}$ & $\mathrm{Eu}$ & Gd & $\mathrm{Tb}$ & Dy & Ho & $\mathrm{Er}$ & $\mathrm{Tm}$ & $\mathrm{Yb}$ & $\mathrm{Lu}$ & $\mathrm{La}$ \\
\hline $\begin{array}{l}\text { Adsorptio } \\
\text { Capacity } \\
(\mathrm{mg} / \mathrm{g})\end{array}$ & 10.9 & 11.1 & 11.3 & 12.0 & 12.2 & 12.5 & 12.8 & 13.1 & 13.4 & 13.4 & 14.0 & 14.4 & 14.6 & 9.8 \\
\hline
\end{tabular}

TABLE IV Tolerance Limits of Coexisting Ions

\begin{tabular}{ll}
\hline Coexisting Ions & Mass Ratio \\
\hline $\mathrm{Na}^{+}, \mathrm{K}^{+}$ & $25,000^{\mathrm{b}}$ \\
$\mathrm{Ca}^{2+}, \mathrm{Mg}^{2+}$ & $10,000^{\mathrm{b}}$ \\
$\mathrm{Fe}^{3+}, \mathrm{Al}^{3+}$ & $500 \mathrm{~b}$ \\
$\mathrm{SiO}_{3}{ }^{2-}, \mathrm{SO}_{4}^{2-}$ & $20,000^{\mathrm{b}}$ \\
$\mathrm{PO}_{4}{ }^{3-}$ & $2500^{\mathrm{b}}$ \\
\hline
\end{tabular}

\footnotetext{
${ }^{a}$ Mass ratio: foreign ion/REE
}

${ }^{\mathrm{b}}$ Maximum amounts tested.
TABLE V

Main Interference on REE Analysis

\begin{tabular}{ll}
\hline Elements & Main Polyatomic Interference \\
\hline${ }^{152} \mathrm{Sm}^{+}$ & ${ }^{136} \mathrm{Ba}^{16} \mathrm{O}^{+}$ \\
${ }^{153} \mathrm{Eu}^{+}$ & ${ }^{137} \mathrm{Ba}^{16} \mathrm{O}^{+},{ }^{136} \mathrm{Ba}^{16} \mathrm{O}^{1} \mathrm{H}^{+},{ }^{136} \mathrm{Ce}^{16} \mathrm{O}^{1} \mathrm{H}^{+}$ \\
${ }^{158} \mathrm{Gd}^{+}$ & ${ }^{142} \mathrm{Pr}^{16} \mathrm{O}^{+},{ }^{142} \mathrm{Ce}^{16} \mathrm{O}^{+},{ }^{142} \mathrm{Nd}^{16} \mathrm{O}^{+}$ \\
${ }^{159} \mathrm{~Tb}^{+}$ & ${ }^{143} \mathrm{Nd}^{16} \mathrm{O}^{+},{ }^{142} \mathrm{Ce}^{16} \mathrm{O}^{1} \mathrm{H}^{+}$ \\
${ }^{164} \mathrm{Dy}^{+}$ & ${ }^{164} \mathrm{Er}^{+},{ }^{148} \mathrm{Sm}^{16} \mathrm{O}^{+},{ }^{148} \mathrm{Nd}^{16} \mathrm{O}^{+}$ \\
${ }^{166} \mathrm{Er}^{+}$ & ${ }^{150} \mathrm{Sm}^{16} \mathrm{O}^{+},{ }^{150} \mathrm{Nd}^{16} \mathrm{O}^{+}$ \\
${ }^{174} \mathrm{Yb}^{+}$ & ${ }^{158} \mathrm{Gd}^{16} \mathrm{O}^{+}$ \\
${ }^{175} \mathrm{Lu}^{+}$ & ${ }^{159} \mathrm{~Tb}^{16} \mathrm{O}^{+},{ }^{158} \mathrm{Gd}^{16} \mathrm{O}^{1} \mathrm{H}^{+}$ \\
\hline
\end{tabular}


based on three times the standard deviation of the blank solution. The relative standard deviation (RSD) for the determinations of the REEs at the 1-ng $\mathrm{mL}^{-1}$ level was less than $5 \%$ when processing $50 \mathrm{~mL}$ of sample solution.

\section{Analytical Application}

In order to establish the validity of the proposed procedure, the method was applied to the determination of the REEs in standard reference material SPS-SW1 Surface Water (LGC Standards, U.K ). The results, summarized in Table VI, show that the determined values are in good agreement with the certified values. The proposed method was applied to the determination of REE ions in deep groundwater and various amounts of analytes were also spiked into the groundwater sample. The results listed in Table
VII indicate that the recoveries were reasonable for trace analysis and ranged from $97.4 \%-101.3 \%$.

\section{CONCLUSION}

In this study, a robust and sensitive solid phase extraction procedure was developed using MWNTs as adsorbent for the ICP-Ms determination of REEs in deep groundwater samples. This SPE procedure including extraction and preconcentration takes 38.5 minutes. Using this method, 150 samples can be processed during an 8-hour work day. The enrichment factors were typically 25-fold, affording detection limits within the 0.31-1.2 $\mathrm{ng} \mathrm{L}^{-1}$ range. The MWNTs possess a higher adsorption capacity towards the REEs, and the analytes retained on the MWNTs can be easily desorbed by $1 \% \mathrm{HNO}_{3}$. In summary, the use of MWNTs is likely to become a great potential solid phase extraction sorbent for the separation, preconcentration, and determination of ultra-trace rare earth elements in various samples.

\section{ACKNOWLEDGMENT}

This research was supported by the Strategic Priority Research Program of the Chinese Academy of Sciences (Grant No.

XDB01020300). Partial support was also provided by the State Key Laboratory for Coal Resources and Safe Mining, China University of Mining \& Technology (Grant No. SKLCRSM12KFA02), and the National Natural Science Foundation of China (Grant No. 41202182).

Received June 16, 2015.
TABLE VI

Analysis Results of REEs in Reference Material SPS-SW1 Surface Water

\begin{tabular}{lcll}
\hline & $\begin{array}{c}\text { Certified } \\
\left(\mathrm{ng} \mathrm{L}^{-1}\right)\end{array}$ & $\begin{array}{c}\text { Found } \\
\left(\mathrm{ng} \mathrm{L}^{-1}\right)\end{array}$ & $\begin{array}{c}\text { Recovery } \\
(\%)\end{array}$ \\
\hline $\mathrm{La}$ & $500 \pm 10$ & $495 \pm 14$ & 99.0 \\
$\mathrm{Ce}$ & $500 \pm 10$ & $510 \pm 10$ & 102 \\
$\mathrm{Pr}$ & $500 \pm 10$ & $508 \pm 8$ & 102 \\
$\mathrm{Nd}$ & $500 \pm 10$ & $508 \pm 8$ & 102 \\
$\mathrm{Sm}$ & $500 \pm 10$ & $498 \pm 2$ & 99.6 \\
$\mathrm{Eu}$ & $500 \pm 10$ & $510 \pm 8$ & 102 \\
$\mathrm{Gd}$ & $500 \pm 10$ & $511 \pm 8$ & 102 \\
$\mathrm{~Tb}$ & $500 \pm 10$ & $506 \pm 6$ & 101 \\
$\mathrm{Dy}$ & $500 \pm 10$ & $516 \pm 12$ & 103 \\
$\mathrm{Ho}$ & $500 \pm 10$ & $513 \pm 13$ & 103 \\
$\mathrm{Er}$ & $500 \pm 10$ & $498 \pm 5$ & 99.6 \\
$\mathrm{Tm}$ & $500 \pm 10$ & $510 \pm 6$ & 102 \\
$\mathrm{Yb}$ & $500 \pm 10$ & $503 \pm 7$ & 101 \\
$\mathrm{Lu}$ & $500 \pm 10$ & $508 \pm 3$ & 102 \\
\hline $\mathrm{Conc}$
\end{tabular}

Concentrations of reference material SPS-SW1 were derived by analyzing a 1:10 dilution.
TABLE VII

Analytical Results and Recoveries of REEs in Deep Groundwater Sample

\begin{tabular}{llcrc}
\hline & \multicolumn{1}{c}{$\begin{array}{c}\text { Found } \\
\left(\mathrm{ng} \mathrm{L}^{-1}\right)\end{array}$} & $\begin{array}{c}\text { Added } \\
\left(\mathrm{ng} \mathrm{L}^{-1}\right)\end{array}$ & $\begin{array}{c}\text { Total Found } \\
\left(\mathrm{ng} \mathrm{L}^{-1}\right)\end{array}$ & $\begin{array}{c}\text { Recovery } \\
(\%)\end{array}$ \\
\hline $\mathrm{La}$ & $25.6 \pm 0.15$ & 20 & $46.2 \pm 0.20$ & 101 \\
$\mathrm{Ce}$ & $19.8 \pm 0.3$ & 20 & $38.8 \pm 0.8$ & 97.5 \\
$\mathrm{Pr}$ & $5.26 \pm 0.22$ & 10 & $15.1 \pm 0.40$ & 98.9 \\
$\mathrm{Nd}$ & $15.3 \pm 0.6$ & 10 & $24.8 \pm 1.1$ & 98.0 \\
$\mathrm{Sm}$ & $4.78 \pm 0.14$ & 10 & $14.9 \pm 0.23$ & 101 \\
$\mathrm{Eu}$ & $1.09 \pm 0.03$ & 2 & $3.01 \pm 0.06$ & 97.4 \\
$\mathrm{Gd}$ & $3.91 \pm 0.21$ & 10 & $13.6 \pm 0.32$ & 97.7 \\
$\mathrm{~Tb}$ & $1.82 \pm 0.01$ & 2 & $3.76 \pm 0.07$ & 98.4 \\
$\mathrm{Dy}$ & $4.32 \pm 0.11$ & 10 & $14.1 \pm 0.21$ & 98.5 \\
$\mathrm{Ho}$ & $1.96 \pm 0.06$ & 2 & $3.91 \pm 0.17$ & 98.7 \\
$\mathrm{Er}$ & $3.82 \pm 0.12$ & 10 & $13.9 \pm 0.14$ & 101 \\
$\mathrm{Tm}$ & $1.72 \pm 0.02$ & 2 & $3.68 \pm 0.04$ & 98.9 \\
$\mathrm{Yb}$ & $3.08 \pm 0.08$ & 10 & $13.1 \pm 0.05$ & 99.9 \\
$\mathrm{Lu}$ & $1.23 \pm 0.04$ & 2 & $3.17 \pm 0.03$ & 98.1 \\
\hline
\end{tabular}




\section{REFERENCES}

1. G. Strauch, M. Moder, R. Wennrich, K. Osenbruck, H.R. Glaser, T. Schladitz, C. Muller, K. Schirmer, F. Reinstorf and M. Schirmer, J. Soil Sed. 8, 23 (2008).

2. P.L. Smedley, Geochim. Cosmochim. Acta 55, 2767 (1991).

3. G. Klinkhammer, C.R. German, H. Elderfield, M.J. Greaves and A. Mitra, Mar. Chem. 45, 179(1994).

4. B.K. Esser, A. Volpe, J.M. Kenneally and D.K. Smith, Anal. Chem. 66, 1736 (1994).

5. L.Halicz, I. Segal and O. Yoffe, J. Anal. At. Spectrom. 14, 1579 (1999).

6. H. Elderfield and M.J. Greaves, Nature 296, 214 (1982).

7. H.J.W. De Baar, M.P. Bacon and P.G. Brewer, Nature 301, 324 (1983).

8. T. Prasada and R. Kala, Talanta 63,949 (2004).

9. G Bayon, D Birot, C Bollinger and J.A. Barrat, Geostds. and Geoanal. Res. 235,145 (2011).

10. N Freslon, G Bayon, D Birot, C Bollinger and $\mathrm{J}$ A Barrat, Talanta 85 , 582 (2011).

11. R D Abreu and C A Morais, Minerals Engineering 61, 82 (2014).

12. X. Q. Sun, H. M. Luo and S. Dai, Talanta 42, 8270 (2013).

13. X. Q. Sun, H. M. Luo and S. Dai, Talanta 90,132 (2012).

14. S. W Su, B. B. Chen, M. He, B. Hu and Z. W. Xiao, Talanta 119, 458 (2014).

15. C. Karadas and D. Kara, Water, Air \& Pollution 225, 2192 (2014).

16. Y. B. Zhu and A. Hioki, K. Chiba, J. Anal. At. Spectrom. 28,883(2013)

17. Q Jia, X F Kong, W H Zhou and L H Bi, Microchem. J., 89, 82 (2008).

18. Y. Tomobuchi, Y. Tachibana, M. Nomura and T Suzuki, J. Radioanal. and Nuclear Chem. 303, 1425 (2015).

19. V. Camel, Spectrochim. Acta B 58, 1177 (2003).

20. I.S. Trujillo, E.V. Alonso, A.G. Torres and J.M.C. Pavón, Microchem. J. 101, 87 (2012)
21. Y. Q. Cai, G. B. Jiang, J. F. Liu and Q. .X Zhou, Anal. Chem. 75, 2517 (2003).

22. P. Liang, Y. Liu, L. Guo, J. Zeng and H. B .Lu, J. Anal. At. Spectrom. 19,1489 (2004)

23. A. H. El-Sheikh, J. A. Sweileh and Y. S. Al-Degs, Anal. Chim. Acta 604, 119 (2007).

24. A. F. Barbosa, M. G. Segatelli, A.C. Pereira, A. S. Santos, L. T. Kubota, P. O. Luccas and C. R. T. Tarley, Talanta 71, 1512.(2007).

25. M. Tuzen, K. O. Saygi and M. Soylak, J. Hazard. Mater. 152, 632 (2008).

26. A. Duran, M. Tuzen and M. Soylak, J. Hazard. Mater. 169, 466 (2009).

27. P. Liang, Y. Liu and L. Guo, Spectrochim. Acta B, 60,125 (2005).

28. J. Munoz, M. Gallego and M. Valcarcel, Anal. Chem. 77, 5389 (2005). 